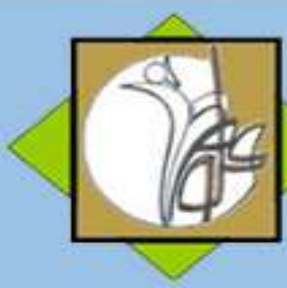

\author{
Research Article
}

\title{
The Effectiveness of Cognitive-Motor Exercises on the Motor Development of Children with Autism Based on Gentile's Two-Stage Model
}

\author{
Seyyed Hojat Zamani sani', Vahid Hassanpour², Zahra Fathi Rezaei ${ }^{3}$, Amir Ghiami Rad ${ }^{4}$ \\ 1. Seyyed Hojat Zamani sani, (Ph. D) University of Tabriz. Tabriz. Iran. \\ 2. Vahid Hassanpour, (Ph. D Student) Shahid Beheshti University, Tehran, Iran. \\ 3. Zahra Fathi Rezaei, (Ph. D) University of Tabriz. Tabriz. Iran. \\ 4, Amir Ghiami Rad, (Ph. D) University of Tabriz. Tabriz. Iran.
}

\section{ARTICLE INFO}

Received May 2019

Accepted April 2020

\section{KEYWORDS:}

Cognitive-motor exercises, autism, fine and gross motor skills, motor development, Gentile's model

CITE:

Zamani sani, Hassanpour, Fathi Rezaei, Ghiami Rad. The Effectiveness of Cognitive-Motor Exercises on the Motor Development of Children with Autism Based on Gentile's TwoStage Model, Research in Sport Management \& Motor Behavior, 2021: 11(21): 109-123

doi $10.52547 / J R S M .11 .21 .109$

\section{ABSTRACT}

The prevalence of autism spectrum disorders (ASD), as a developmental neurological condition, has increased in recent years. The present study aimed to investigate the effectiveness of cognitive-motor exercises on the improvement of some large and delicate motor skills of children with autism based on Gentile's Two-Stage Model. In the present Semi-experimental study, one of the rehabilitation centers under the supervision of Tehran Welfare Organization was selected as via the convenience sampling method and 20 children aged 6-10 years with autism were randomly divided into two homogeneous experimental and control groups. The subjects in the experimental group participated in a six-week training protocol (three sessions per week). Each session was made up of 60 minutes of cognitive-motor exercises based on Gentile's model. Bruininks-Oseretsky subtests of motor proficiency were employed for data collection. The collected data were analyzed using the repeated measures ANOVA. The results indicated that after cognitive-motor training, running and agility skills, static and dynamic balance, upper limb coordination and response speed in the experimental group increased significantly $(p<0.05)$. As the findings showed, cognitive-motor exercises designed as a useful method can be used to rehabilitate the fine and gross motor skills of children with autism. 


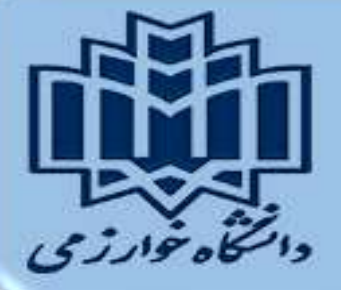

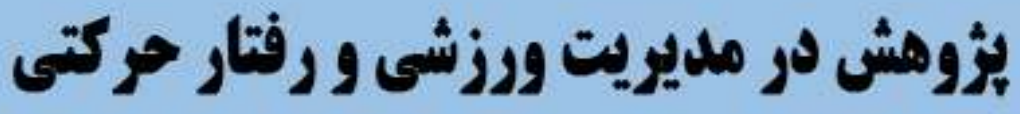

مقاله بُؤهنى

\section{تاثير تمرينات شناختى-حر كتى طبق مدل جنتايل بر رشد حر كتى كودكان مبتلا به اوتيسم}

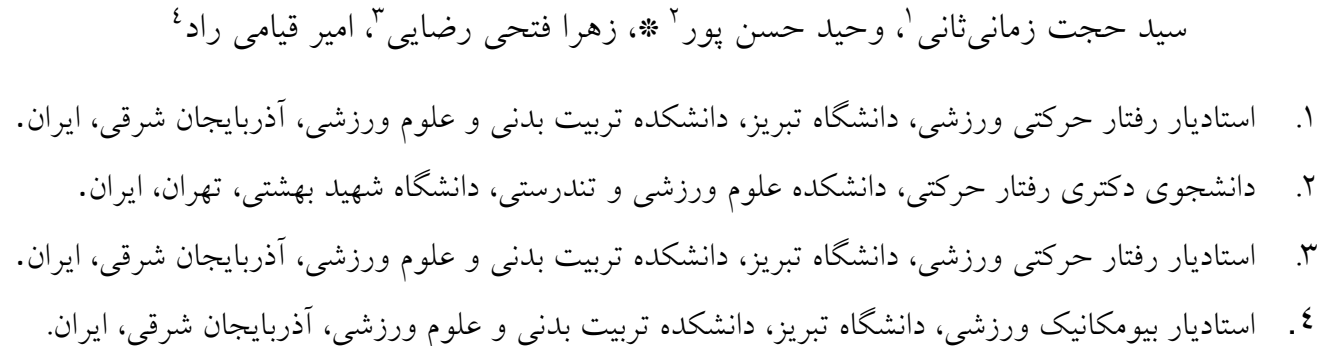

\section{جكيله}

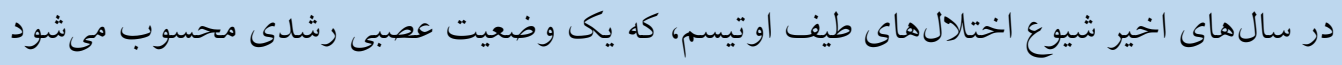

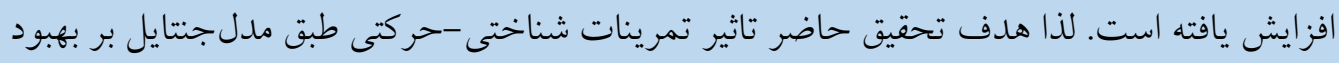
برخى از مهارتهاى حركتى درشت و ظريف كودكان مبتلا به اوتيسم بود. در مطالعه نيمها آزمايشى نائن

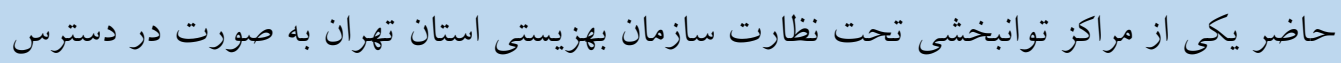
انتخاب و •r كودى 7- •-1 ساله دجار اختلال اوتيسم به صورت تصادفى ساده در دو گروه همكن

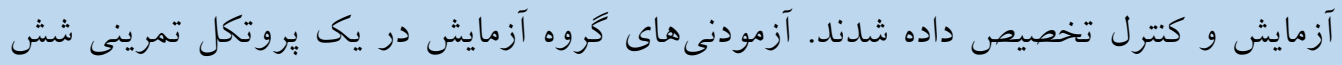
هغتهاى (سه جلسه در هفته) شركت كردند. هرجلسه تمرين شامل •7 دقيقه تمرينات شناختى

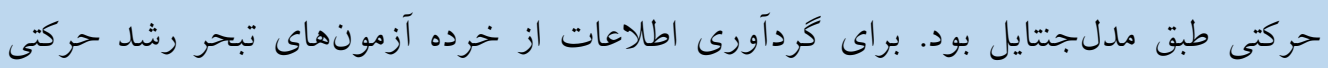

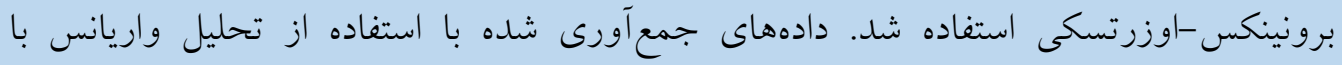

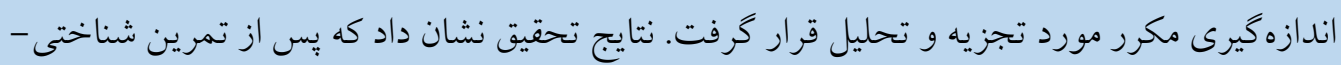

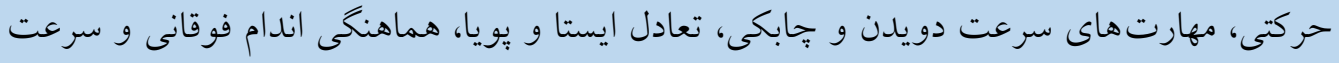

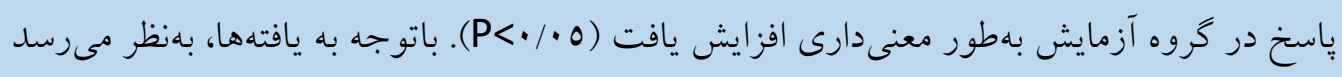

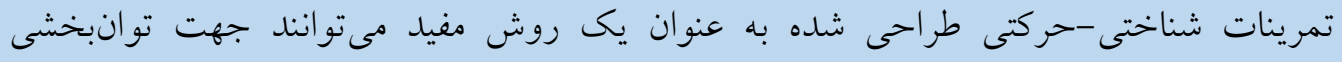
مهارتهاى درشت و ظريف رشد حركتى كودكان مبتلا به اوتيسم مورد استفاده قرار كيرند.
\end{abstract}

اطلاعات مقاله:

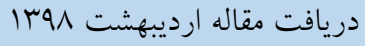

بذيرش مقاله ارديبهشت 994ه

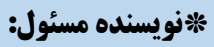

vahid.hassanpour1991@gmail.com

وازه هاى كليدى:

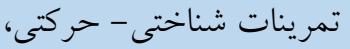

اوتيسم، مهارتهاى حركتى

درشت و ظريف، مدل جنتايل

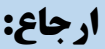

زمانىثانى ، حسن يور ، فتحى رضايى ، قيامى راد. تاثير تمرينات

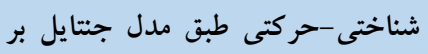
رشد حركتى كودكان مبتلا به اوتيسم. يزوهش در مديريت ورزشى و رفتار

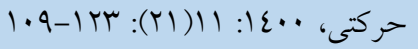


اختلال اوتيسم نوعى بيمارى يا اختلال در سيستم عصبى رشدى مى باشد (1). نتيجه جنين نارسايىهاى اختلالاتى عملكردى و با توجه به ماهيتى كه اين اختلال دارد، مشكلات عديدهاى را براى افراد مبتلا، خانواده و سازمانهايى كه وظايف تعليم و تربيت اين افراد را بر عهلده دارند، به وجود مى آورد (Y). حركات كليشهاى، نقص بارز در برقرارى ارتباط با ديخران و اختلال شديد در تعاملات اجتماعى، از ويزّىىهاى تشخيص اختلال طيف اوتيسم است (ب). براساس آمار سال

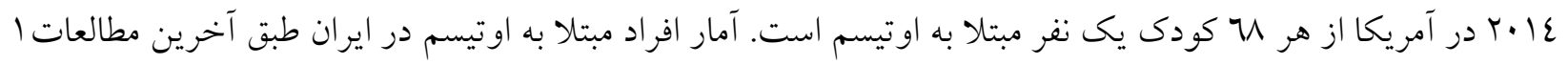

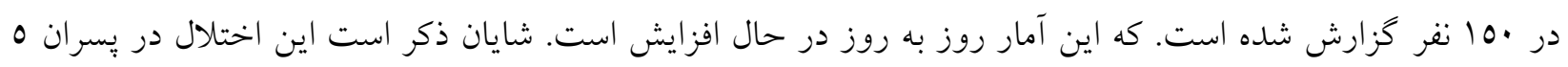
برابر بيشتر از دختران كزارش شده است (ع). مسئله درمان او تيسم و نحوه برخورد با اين كودكان و مشكلات مربوط به سيستم آكاهى، شناخت و توجه، از معضلات

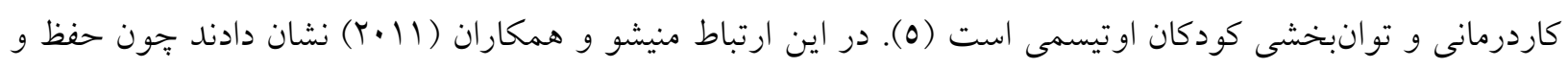

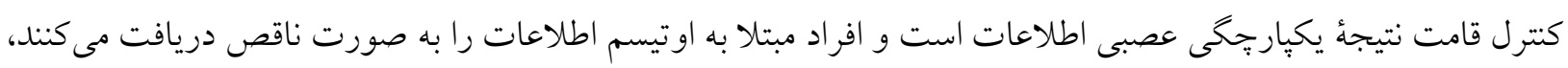

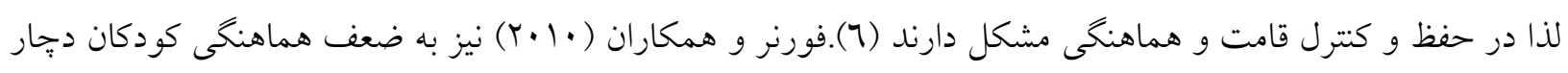
اوتيسم اشاره كرده و عنوان كردند كه اين كودكان نقص حركات داشته و به كنترل قامت نياز دارند و جون تعادل كافى

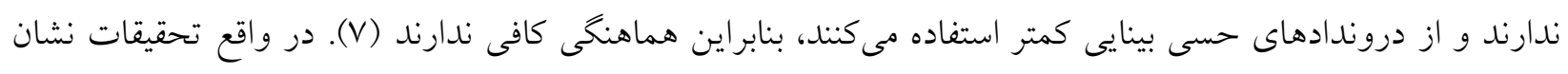
مىدهند كه بسيارى از رفتارهاى اين افراد دجار اختلال مىشود. بلوم (1907) در نظريه خود تمام رفتارهاى انسان را در درى سه حوزه شناختى، عاطفى و روانى - حركتى تقسيم بندى كرده است كه به طور غير قابل تفكيكى دائماً با هم تعامل دارند.

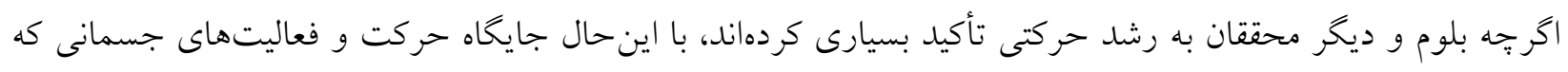

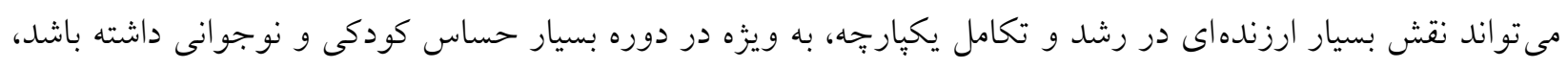

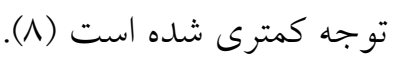
احتمالاً مشكلات برنامهريزى و اجراى جنين فعاليتهايى براى افراد، بسيارى از محققين را از اين زمينه جدا كرده است. فقر مهارتهاى حركتى مىتواند تأثير دراز مدت و قابل توجهى بر رشد اجتماعى و رفتارى افراد داشته باشد (9) (9). همجنين بندين مى تواند موجب كاهش شركت در فعاليتهاى بلدنى شود. در نهايت اين نتايج خطرهايى را براى سلامت اين افراد به همراه

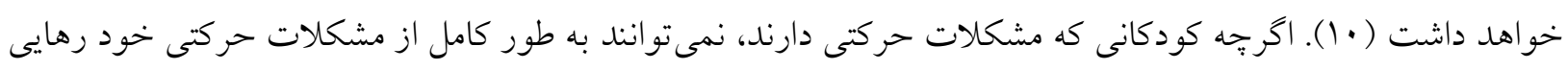
يابند، ممكن است با شركت در فعاليتهاى بدنى كه بر ياد گيرى مهارتهاى حركتى متمركز است، سطح مهارتهاى خود

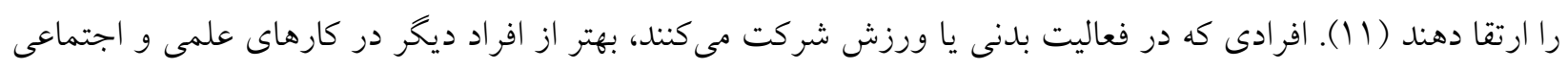

موفق هستند. به همين دليل، استفاده از فعاليت بدنى يا ورزش براى افراد اوتيسم مى توانند مفيد باشد (r (1).

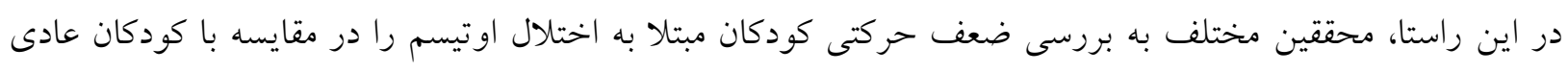

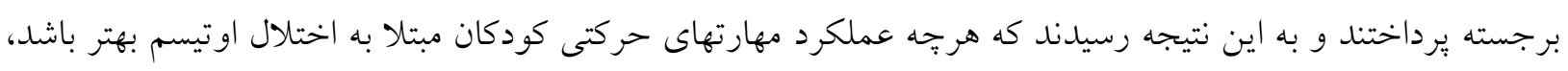

\section{https://jrsm.khu.ac.ir/}




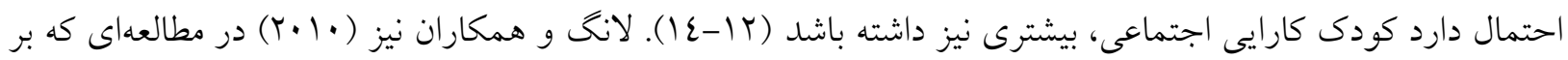
روى كودكان اوتيسم انجام دادند، مهارتهاى حركتى درشت اين كودكان را در مقايسه با كودكان همسال سالم و عقب مانده ذهنى ضعيف گزارش نمودند و علت اين ضعف را در كيفيت اجراى مهارت دانستند (10). همجنين طبق نظريه دلاكاتو نقش حركت و فعاليت در سازماندهى مغز مهم است. به همين دليل نداشتن تجربيات حركتى كافى در دورههاى مختلف رشدى، به ويزه در دوران نوزادى و كودكى مىتواند آثار نامطلوبى بر رشد ساختمان عصبى بويزه مغز انسان داشته باشد (7) (1). دراين راستا شواهد تجربى نشان مىدهد تمرين در يك محيط جالش برانگيز از نظر شناختى نسبت به تمرينات جسمانى به تنهايى در توليد مزاياى شناختى و عصبى اثر بخشتر هستند و تركيبى از تمرين

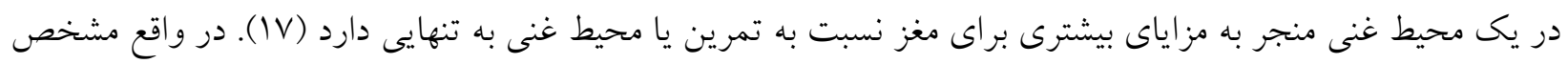
شده است مداخلاتى با تركيب تمرين جسمانى و شناخت درمانى كه به طور متوالى يا همزمان ارائه مىشود در ايجاد و

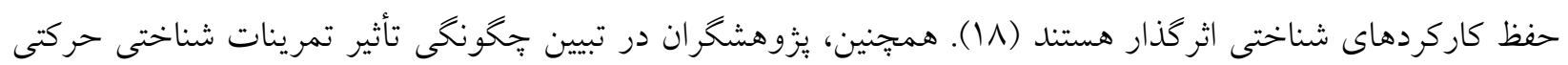
بر جنبه هاى شناختى به فرايندها و سازو كارهاى فيزولوزيكى و عصبشناسى اشاره كردهاند. به عنوان مثال ووس و همكاران

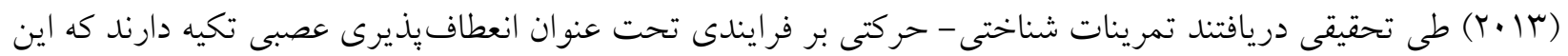
تمرينات در مغز مىتواند ارتباطات نورونى جديد ايجاد كند. براين اساس مغز مىتواند در بِاسخ به تحريكات خاص، فعاليت خود را تعديل كند (9 (1). از اينرو بيشنهاد شده است كه تمرينات شناختى - حركتى مى تواند استمرار در دوره تمرين را افزايش دهد، جرا كه اين تمرينات داراى تنوع، هدف گذارى واقع بينانه، توجه به تفاوتهاى فردى، بازخورد فورى و تقويت مثبت هستند و ميزان بالاى تمرينات باعث مىشود مزاياى كسب شده بيشتر از برنامههاى سنتى درمانى باشد (•).

علاوه براين، يكى ديخر از مشكلات كودكان مبتلا به اوتيسم كه مانع اجراى مناسب تمرينات مىشود، رفتارهاى نامتعادل و ناهماهنخ آنهاست. اين رفتارها نه تنها سدى در برابر كودى و مربى است، بلكه مانعى براى يادكيرى بهينهُ مهارتهاى

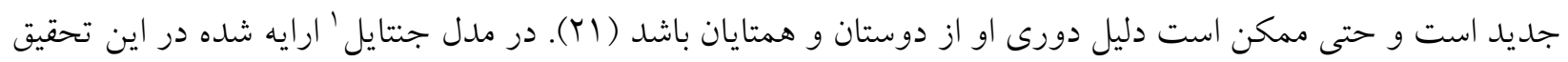
دستورالعمل هاى ارايه شده در مرحله اكتساب درك اينكه جهه انجام شود تا يك ايده عمومى از الكوى حركتى لازم شكل بكيرد را ممكن مى سازد (YT). مدل جنتايل بر دو بعد مهم استوار است. اولين بعد با بافت محيطى در ارتباط است كه مهارت در آن اجرا مى شود. دو ويزگگى بافت در اين بعد دخالت دارند. اولين ويزَّى محيطى شرايط تنظيم كننده است. شرايط تنظيم كننده، ويز كى هاى از بافت محيطى است كه خصوصيات حركت را كنترل مى كنند. يعنى براى كسب موفقيت حركات شخص بايد با اين خصوصيات محيطى تطبيق يابد. براى مثال شخصى كه شخص بر روى آن راه مى رود، حركات فردى را كه براى راه رفتن از آن سطح استفاده مى كنند تحت تاثير قرار مى دهد. دومين ويزگى محيطى در اين طبقه بندى، تغيير بين كوشش است. به اين مفهوم كه شرايط تنظيم كنندگى اجرا، از يك اجرا تا اجراى ديخر ممكن است يكسان يا

\section{${ }^{1}$ Gentile}

https://jrsm.khu.ac.ir/ 
متفاوت باشد. اين طبقه بندى اساس بسيار خوبى را براى فهميدن نيازهاى اجرا كننده به انواع مهارتهاى حركتى مى باشد

اما آنجه كه كمتر به آن يُرداخت شده كاربرد اين مدل در روش هاى مختلف تمرين است. زيرا به نظر مى رسد استفاده از روشهاى تمرين متفاوت بر مبناى اين مدل مى تواند به غناى نظرى تفاوتهاى اين روش تمرين بيفزايد. موضوعى كه مى

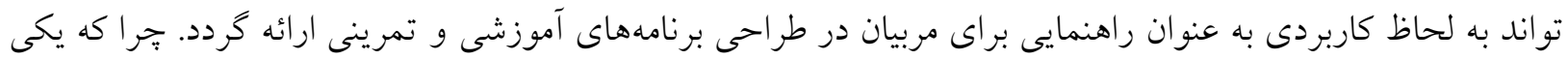

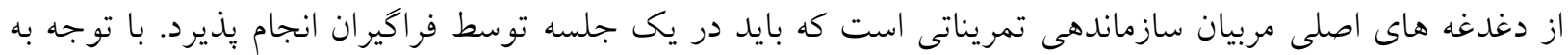
اهميت اين مسئله كه دورة كودكى از مهمترين دورههاى رشد در طول زندكى بشر است و جبران كمبودهاى ايجاد شده در اين دوره در ساليان بعد دشوار يا حتى ناممكن است، تشخيص به موقع مشكلات رشدى و مداخلئ درمانى زود هنگام در اين كودكان باعث مىشود تا مهارتهاى بيشنياز لازم براى موفقيت در آينده را در اين دوران حساس به خوبى بـ بـ بـ فرابخيرند.

از اينرو با توجه به اهميت مهارتهاى بنيادى، مطالعات اندكى تاثير فعاليتهاى حركتى و تمرينات بدنى بر مهارتهاى

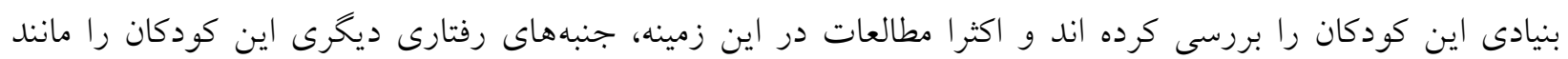
رفتارهاى كليشه اى را مورد توجه قرار داده اند (10). همجنين با درنظر كرفتن شواهد موجود در زمينهُ اهميت مفهوم تمرينات شناختى - حركتى در كودكان دجار اوتيسم زمينهُ تأثير تمرينات شناختى - حركتى و بِيامدهاى رفتارى رونى آنها، استنباط مى شود كه مداخلات تمرينى شناختى - حركتى مىتواند بر جنبههاى مورد بررسى كودكان اوتيسم تأثير داشته

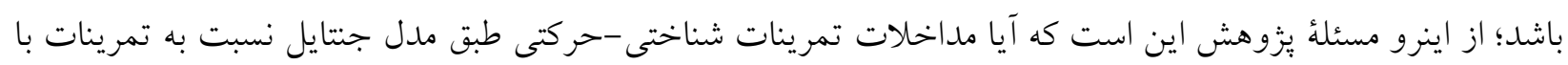
شكلهاى رايج، در بهبود برخى از مهارتهاى درشت و ظريف رشد حركتى كودكان كودكان مبتلا به اوتيسم تاثير بيشترى

$$
\text { را ايجاد خواهد كرد؟ }
$$

\section{روش شناسى}

روش يزوهش حاضر نيمه آزمايشى و طرح تحقيق از نوع ييش آزمون - يس آزمون با گروه كنترل است. جامعهُ آمارى آن همه كودكان ييش دبستانى 1-• إناله داراى اختلال طيف اوتيسم مراجعه كننده به يكى از كلينيكهاى شهر تهران در سال Vوسا بودند. حجم نمونهُ يُزوهش ·r نفر بود با استفاده از روش نمونه گيرى دردسترس از بين مذكور انتخاب شده و

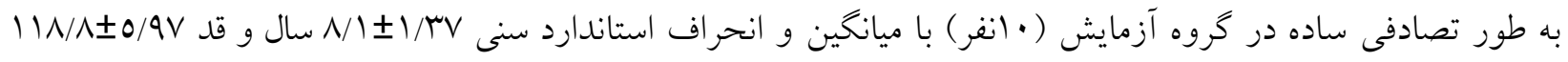

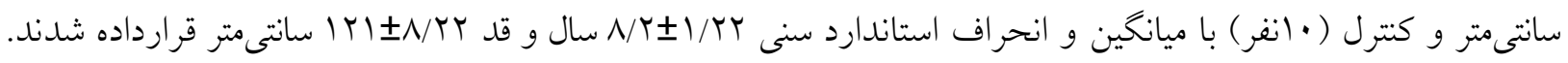
قبل از شروع يزوهش از والدين كودكان خواسته شد تا در صورت تمايل و اعلام موافقت آكاهانه، با تكميل رضايتنامه در مطالعه شركت كنند. روند اجراى تمرينات به طور كامل و شفاف به صورت عملى آموزش داده شد و به والدين شرح داده شد كه اين يزوهش جه از نظر مداخله و جه از نظر روشهاى ارزيابى خطر و آسيبى ندارد. همجنين اهميت نقش 
درمانهاى غيردارويى اعلام و سيس اثرات مفيد احتمالى اين نوع درمان بهطور مفصل توضيح داده شد. آزمودنى ها در هر مرحله از يزوهش قادر بودند تا به هر علتى يزوهش را ترى كنند. ملاكهاى زير براى انتخاب كودكان در نظر كرفته شد: از نظر سنى در دامنه 7 تا • ( سال باشند، هيج گونه اختلال حاد روانيزشكى ديخرى نداشته باشند (با تشخيص روانيزشك)، اختلال جسمى خاص و بارزى نداشته باشند (با تشخيص يزشك)، خانو ادهُ آنان در شر ايط مطلوب اجتماعى و روانى قرار داشته باشد، دجار اختلالات همراه اوتيسم مثل سندروم داون نباشند. براى كردآورى اطلاعات از آزمون تبحر حركتى برونينكس -اوزرتسكى استفاده شد. اين آزمون يكى مجموعه آزمون هنجار

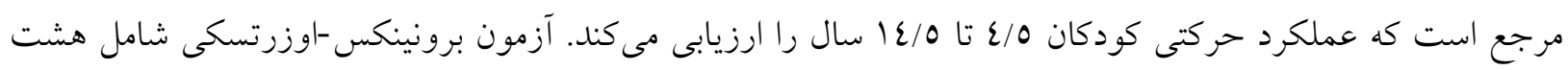

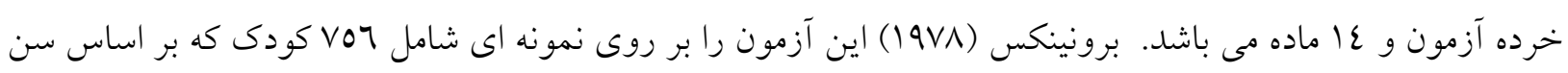
، جنس،نزاد، حجم جامعه و منطقه جغرافيايى مطابق سرشمارى سال •19V انتخاب شده بودند ، استاندارد كرد. ضريب رون

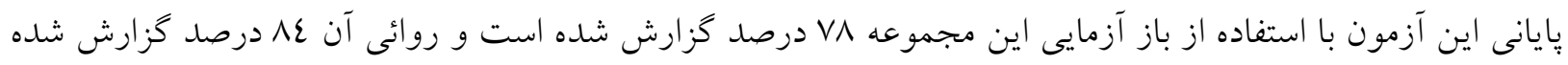

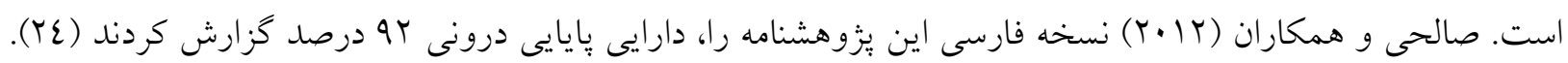

\section{روش اجراى آزمون}

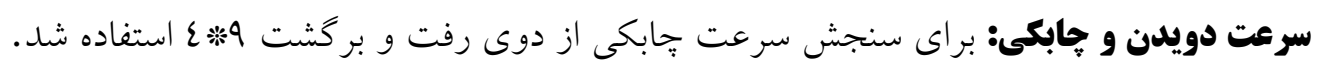

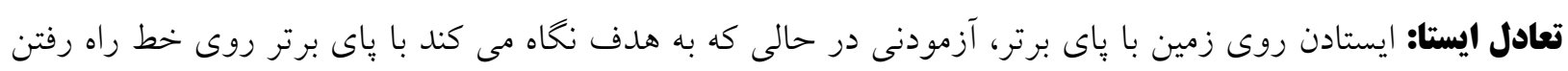

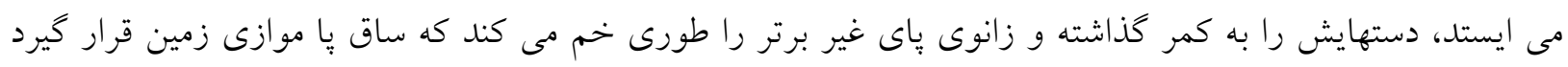

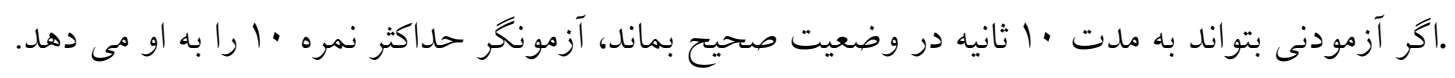
تعادل يويا (راه رفتن روى خط): آزمودنى بايد در حالى كه دست ها را به كمر زده با كام هاى عادى روى خط راه راه رفتن به جلو كام بردارد.آزمونخر تعداد گام هاى صحيح را مى شمارد و در صورت برداشتن كام صحيح به جلو حداكثر امتياز (7)

هماهنكى اندام فوقانى: آزمودنى روى تشك مى ايستد و با علامت شروع توسط آزمونخر، توبٍ تنيس را ه بار به زمين

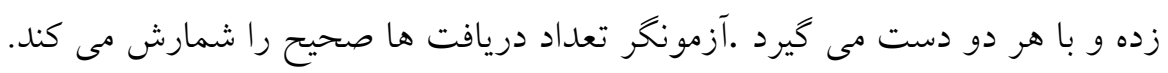

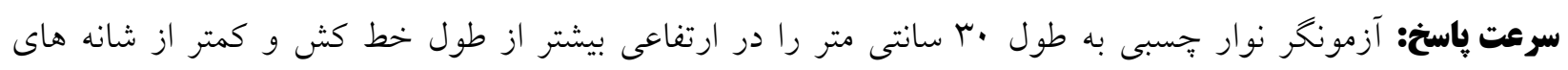

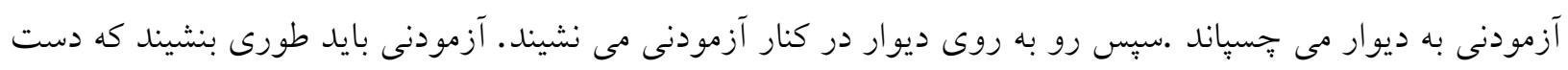

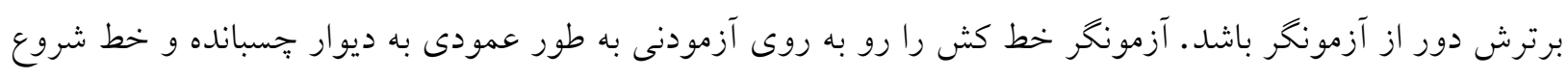

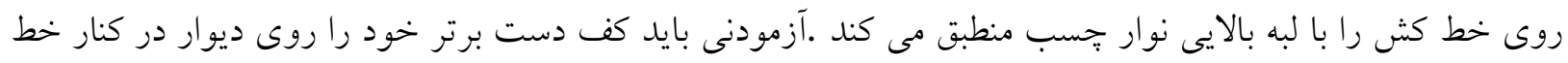

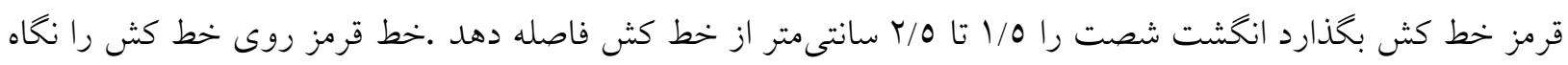

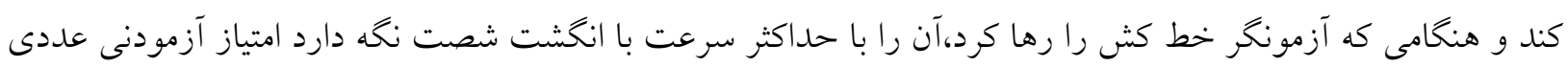
كه بالا نوار جسب مشاهده مى شود. 
روش اجراى يزوهش حاضر به اين صورت بود كه يس از انتخاب نمونهُ مورد نظر، افراد به صورت تصادفى ساده در دو كروه آزمايش و كنترل تقسيم شدند. قبل از اجراى بروتكل از هر دو گروه آزمونهاى سرعت دويدن و پِابكى، تعادل ايستا و يويا، سرعت ياسخ، هماهنكى اندام فوقانى گرفته شد. سيس شركت كنندگان گروه آزمايش در جلسات مداخلهُ

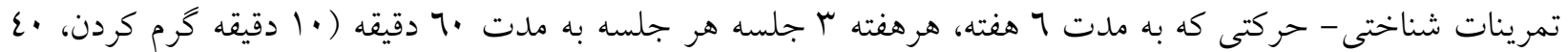

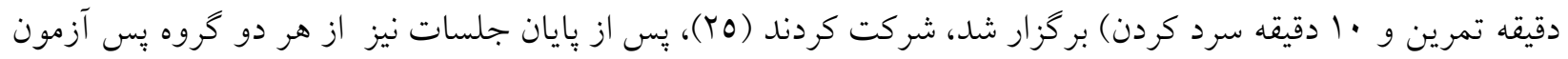
كرفته شد.

قرارداد تمرينى در اين يزوهش شامل تمرينات شناختى - حركتى با توجه به طبقهبندى جنتايل انجام شد كه در شكل شماره ا بيان شده است.

\begin{tabular}{|c|c|c|c|c|}
\hline انتقال بدن: بله & |نتقال بدن: بله & |دستقال بدن: خير & |نتقال بدن: خير & - \\
\hline 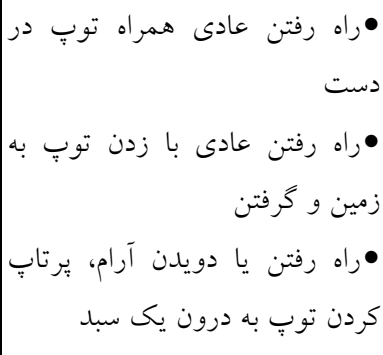 & 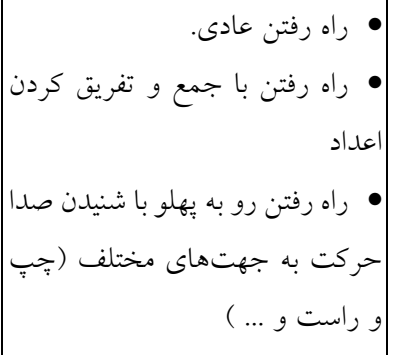 & 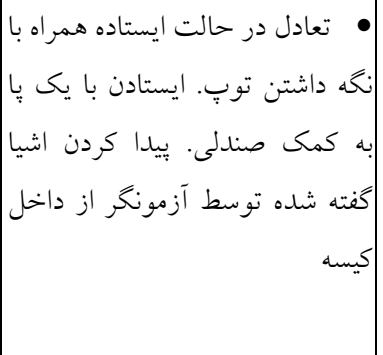 & 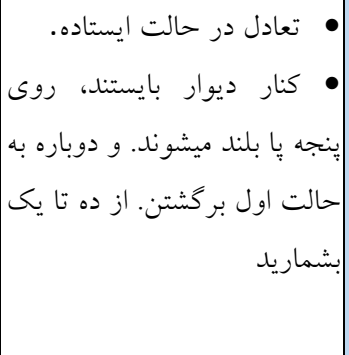 & 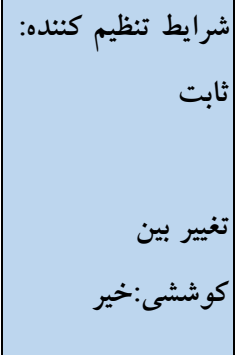 \\
\hline 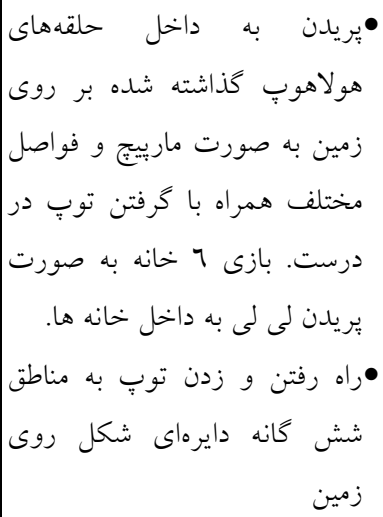 & 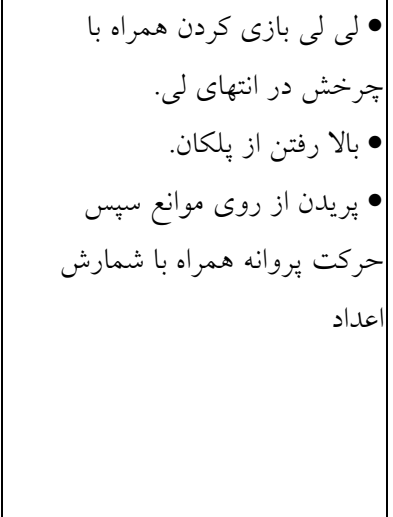 & 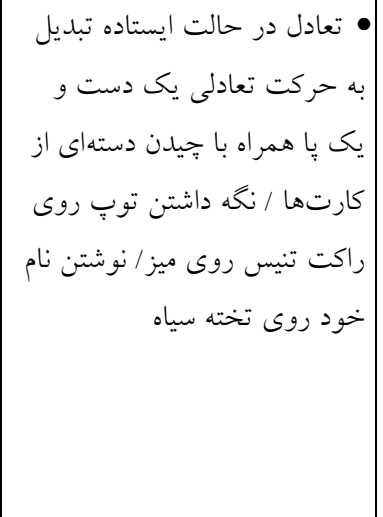 & • & شابت \\
\hline
\end{tabular}




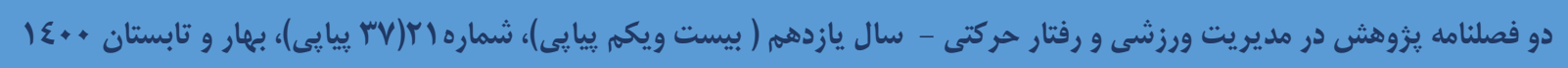

\begin{tabular}{|c|c|c|c|c|}
\hline 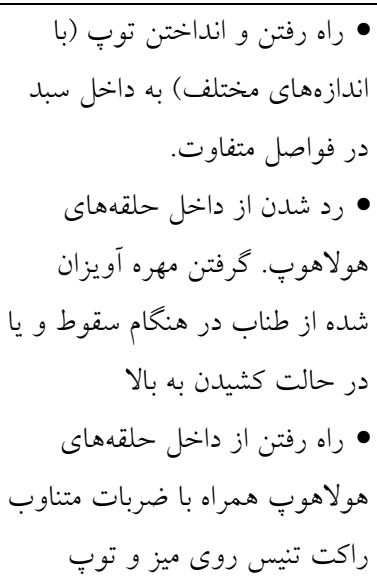 & •• •• •ِ & 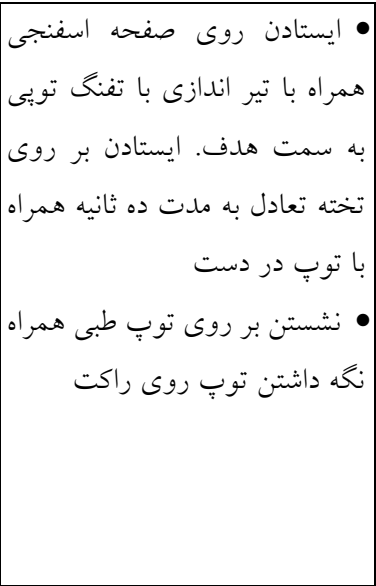 & 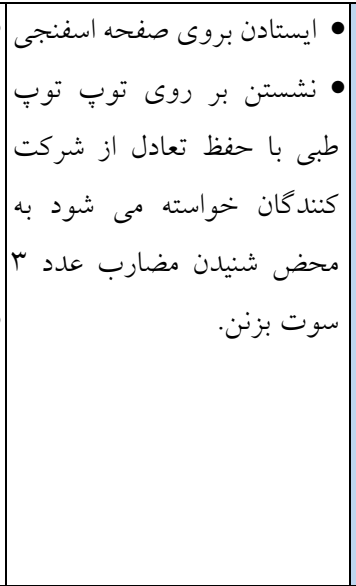 & |متحرى \\
\hline 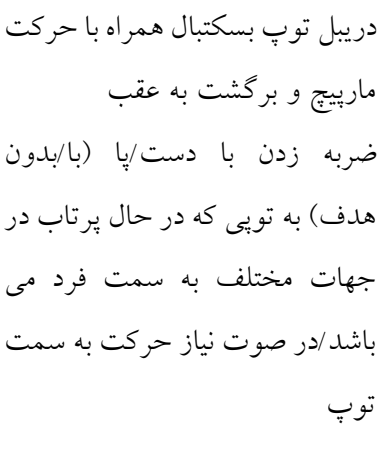 & 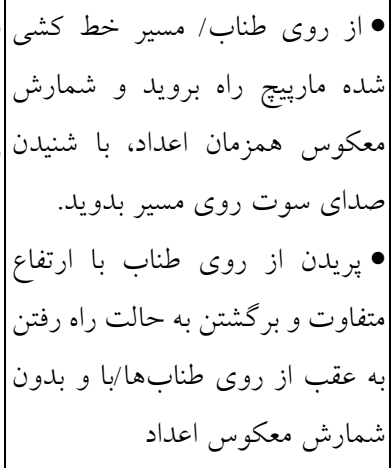 & 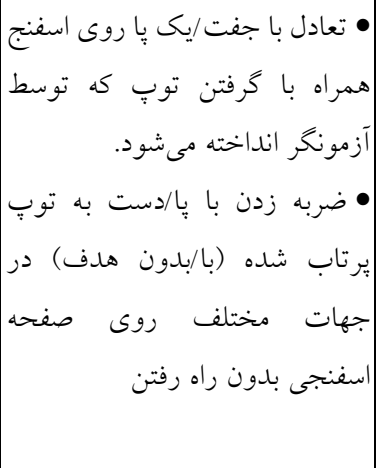 & 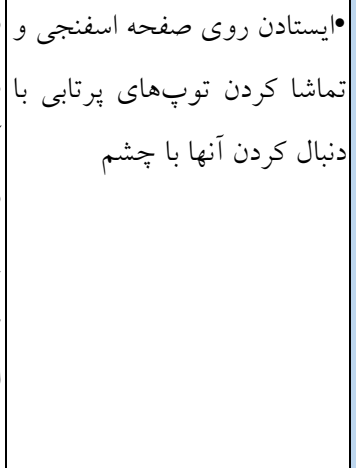 & 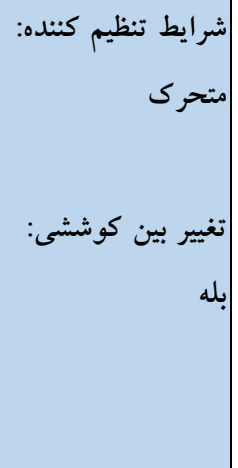 \\
\hline
\end{tabular}

شكل 1. طراحى تمرين براى گروه آزمايش براساس مدل جتنايل

آزمودنىهاى كروه كنترل نيز هيج مداخلهاى دريافت نكردند و اطمينان حاصل شد كه ميزان فعاليت روزانه خود را حفظ كرده و در هيج برنامه توانبخشى منظم شركت نداشتند. در نهايت، از آزمونهاى شاييرو ويلك براى بررسى نرمال بودن

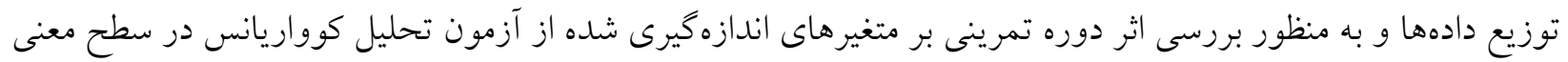
دارى 0 •/ و نرمافزار SPSS نسخه سץ استفاده شد.

نتايج

نتايج آزمون ويلكى-شاييرو براى بررسى توزيع طبيعى دادهها نشان داد كه تمام متغيرهاى مورد مطالعه داراى توزيع طبيعى آنس آنس

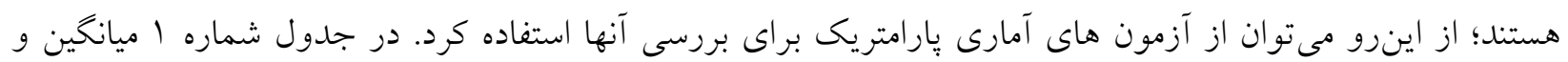
انحراف استاندارد متغيرهاى مورد بررسى بيان شده است. 
جدول ا. شاخصهاى اندازهيرى شده قبل و پِ از مداخله تمرينى

\begin{tabular}{|c|c|c|c|c|c|}
\hline \multicolumn{2}{|c|}{ بֶ آزمون } & \multicolumn{2}{|c|}{ ييش آزمون } & \multirow{2}{*}{ متغييرها } & \multirow{2}{*}{ كروه } \\
\hline انحراف استاندارد & ميانكين & انحراف استاندارد & ميانكين & & \\
\hline.$/ \varepsilon r$ & $r / 0$. & $\cdot / T V$ & $r / \mu$. & تعادل ايستا & كنترل \\
\hline$\cdot / \mu 1$ & $T / T$. & $\cdot / 47$ & $r / \cdot \cdot$ & تعادل يويا & \\
\hline .109 & TY/TY &.$/ 70$ & $r Y / r \Lambda$ & سرعت پاسخ & \\
\hline.$/$ To & $r / \cdot$ & $\cdot / r \varepsilon$ & $1 / 9$. & هماهنكى اندام فوقانى & \\
\hline • $/ 47$ & $r / T V$ & $\cdot / r \mid$ & $r / \cdot 0$ & سرعت دويدن و جابكى & \\
\hline$\cdot / \mu$ & $r / \Lambda$. & $\cdot / T V$ & $T / T$. & تعادل ايستا & آزمايش \\
\hline$\cdot / \mu 1$ & $r / \varepsilon$. &.$/ 47$ & $1 / 9$. & تعادل يويا & \\
\hline .109 & $r \cdot / 77$ &.$/ 70$ & $r / r)$ & سرعت پاسخ & \\
\hline$\cdot / 47$ & $T / V \cdot$ & $\cdot / r \varepsilon$ & $1 / v$ & هماهنگ اندام فوقانى & \\
\hline.$/ 47$ & $r / r$ & $\cdot / r \mid$ & $1 / 9$. & سرعت دويدن و جابكى & \\
\hline
\end{tabular}

در ابتدا، يِي فرض هاى هر يك از آزمونهاى آمارى مانند همخنى بين گروهى، همخنى واريانس ها (آزمون لون) و همخنى كوواريانس (آزمون M باكس) بررسى شد و مورد تاييد قرار كرفت. در ادامه به منظور بررسى اثر دوره تمرينى بر متغيرهاى

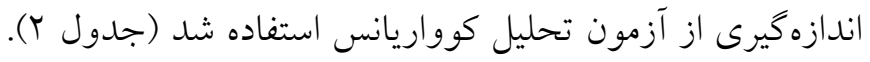

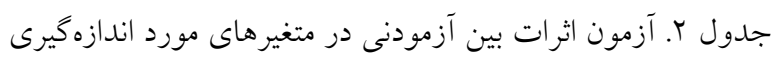

\begin{tabular}{|c|c|c|c|c|c|c|}
\hline مجذور اتاى & معنادارى & F آماره F & ميانخين & دازادى & $\begin{array}{c}\text { مجموع مجذورات } \\
\text { III نوع }\end{array}$ & متغير \\
\hline$\cdot / r \varepsilon q$ & $\cdot / \cdot \wedge$ & $9 / 11 \varepsilon$ & $\varepsilon / 91$ & 1 & $\varepsilon / 9 \wedge$ & دويدن و جابكى \\
\hline$\cdot / \pi \wedge 9$ & $\cdot / \cdots \varepsilon$ & $1 \cdot / 110$ & $V / 9 V T$ & 1 & $V / 9 V T$ & تعادل يويا \\
\hline$\cdot / T V T$ & $\cdot / \cdot r r$ & T/Mrq & $9 / \varepsilon \wedge 1$ & 1 & $q / \varepsilon \wedge 1$ & تعادل ايستا \\
\hline$\cdot / r$ & .1 .00 & $\varepsilon /$ Tor & $r / \Lambda$ & 1 & $r / \Lambda$ & هماهنكى اندام فوقانى \\
\hline$\cdot / \varepsilon \cdot 1$ & $\cdot / \cdots \varepsilon$ & $11 / \pi \wedge 7$ & $19 / \cdot 9$ & 1 & $19 / \cdot 9$ & زمان واكنش \\
\hline
\end{tabular}

نتايج آزمون يونيوريت با كووريت كردن ييش آزمون ها نشان داد كه تفاوت آمارى معنادارى بين يس آزمون كروهها در متغيرهاى دويدن وجابكىى، تعادل يويا، تعادل ايستا و زمان واكنش وجود دارد. با اينحال در هماهنكى اندام فوقانى تفاوت معنادار نبود. مقايسه دو به دو كروهها نشان داد كه كروه آزمايش وضعيت بهترى نسبت به كروه كنترل دارد (جدول Y). 
جدول rا. مقايسه هاى دو به دو بين گروه هاى مورد بررسى در مراحل ييش آزمون و يّ آزمون

\begin{tabular}{|c|c|c|c|c|c|}
\hline سطح معنادارى & انحراف استاندارد & تفاوت ميانكين (j- i (j) & (j) & (i) & متغير وابسته \\
\hline$\cdot / \cdot \wedge$ & ( & $1 / \cdots 0$ & كتترل & آزمايش & دويدن و جابكى \\
\hline$\cdot / \cdots \varepsilon$ & $\cdot / \% \wedge 0$ & $1 / 470$ & كنترل & آزمايش & تعادل يويا \\
\hline$\%$ \% Y & $\cdot / 0 \sum \Lambda$ & $1 / \Lambda^{*}$ & كنترل & آزمايش & تعادل ايستا \\
\hline 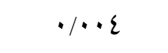 & .1017 & $-1 / 9 \vee q^{*}$ & كنترل & آزمايش & زمان واكنش \\
\hline
\end{tabular}

در ادامه بررسى نتايج درون گروهى نشان داد كه در همه متغيرهاى گروه آزمايش بيشرفت حاصل شده در حالى كه فقط در كروه كنترل متغير دويدن و جابكى با تغييرات منفى همراه بود (جدول ع).

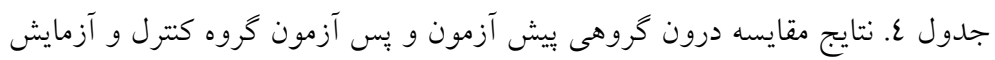

\begin{tabular}{|c|c|c|c|c|c|c|}
\hline معنى دارى & $\mathrm{t}$ & انحراف استاندارد & درجات آزادى & تفاوت ميانكين & آزمونها & كروه \\
\hline.$/ 719$ & $-\cdot / 01 \varepsilon$ & $1 / T Y$ & 9 & $-\cdot / r$ & تعادل ايستا & \multirow{5}{*}{ كتترل } \\
\hline .1000 & $-\cdot / 71 Y$ & $1 / \cdot r$ & 9 & $-\cdot / r$ & تعادل يويا & \\
\hline$\cdot / \Gamma \Lambda \Lambda$ & $\cdot / 9 \cdot V$ & $-1 / T_{0}$ & 9 & $\cdot / \mu$ & سرعت پِاسخ & \\
\hline . / VOA & $-\cdot \pi / \Lambda$ &.$/ 99 \varepsilon$ & 9 & $-\cdot / 1$ & هماهنكى اندام فوقانى & \\
\hline$\cdot / \cdot \varepsilon 1$ & $-r / \mu_{\Lambda}$ &.$/ \varepsilon r \mu$ & 9 & 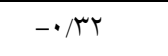 & دويدن و جابكى & \\
\hline$\% r$ & $-\varepsilon / \pi \|$ & $1 / 1 V$ & 9 & $1 / 7$ & تعادل ايستا & \multirow[t]{5}{*}{ آزمايش } \\
\hline$\%+\cdots 1$ & $-7 / V$ & $\cdot / V \cdot V$ & 9 & $1 / 0$ & تعادل يويا & \\
\hline.$/ \cdots 1$ & $0 / . r$ & $1 / 7$ & 9 & $r / 00$ & سرعت پِاسخ & \\
\hline$\cdot / \cdots \wedge$ & $-r / r o$ &.$/ 9 \varepsilon Y$ & 9 & 1 & هماهنكى اندام فوقانى & \\
\hline$\%$. r & $-\varepsilon / \varepsilon)$ &.$/ 1$ & 9 & $1 / \mu \Lambda$ & دويدن و جابكى & \\
\hline
\end{tabular}

در نهايت نتايج آزمون مقايسه يِيش آزمون- يُس آزمون درون گروهى (نتايج آزمون تى همبسته) نشان داد كه يِ إز تمرين

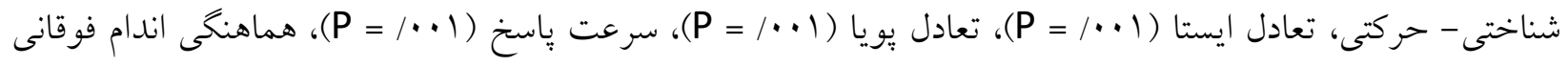

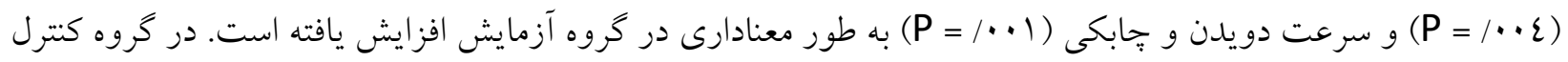
نيز در متغير سرعت دويدن و جابكى (1) تفاوت معنى دارى مشاهده نشد (جدول شماره 0). 
يزوهش حاضر با هدف بررسى تأثير تمرينات شناختى - حركتى طبق مدل جنتايل بر بهبود مهارتهاى درشت و ظريف رشد حركتى كودكان مبتلا به اوتيسم انجام شد. نتايج نشان دهندة اثر مثبت روش تمرينات شناختى - حركتى طراحى شده در افزايش مهارتهاى سرعت دويدن و جابكى؛ تعادل ايستا و يويا، هماهنگى اندام فوقانى و سرعت ياسخ كودكان اوتيسم بود. تحقيق حاضر و نتايج تحقيقات كذشته نشان داد ورزش و فعاليت بدنى باعث بهبود مهارهاى حركتى كودكان مبتلا به اوتيسم مى شود. در همين راستا سووا و مولنبروى (Ylll) نيز در تحقيقات خود نشان داد كه تمرينات فعاليت

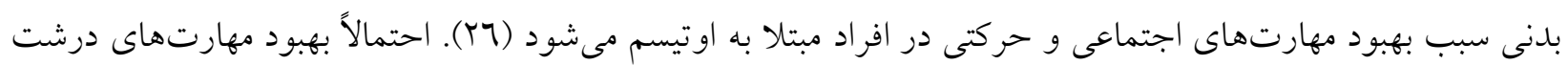
و ظريف كودكان اوتيسمى در تحقيق حاضر و تحقيقات كذشته ، ناشى از بهبود عملكرد فيزيولوزيكى عضلات و سيستم

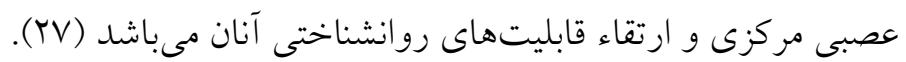
در مقياس تعادل تمرينات شناختى حركتى طبق مدل جنتايل ارايه شده در اين بزوهش، توانسته مهارتهاى تعادل ايستا و يويا را در آزمودنىهاى كروه آزمايش تحت تاثير قرار دهد. با توجه به اينكه شاخصهاى كنترلى وضعى شامل تاخير يا نبودن تعادل، واكنش هاى تعادلى و ناتوانى در نگحه داشتن قامت در كودكان با اختلال اوتيسم تا با سالكى رشد جندانى ندارد و به طور معمول به سطح بزر گسالى نمى رسد، به نظر مى رسد تمرينات بدنى و شناختى زمينه ساز بيشرفت و بهبود اين نارسايىها شود از اين طريق مهارتهاى حركتى ديخر را نيز تقويت كند. اين يافته ها با نتايج سراب زاده و همكاران

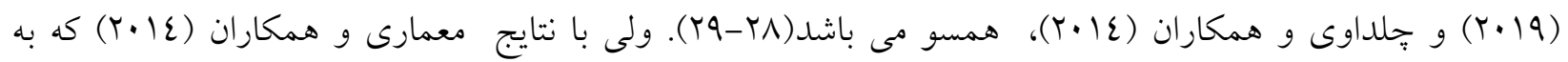
بررسى تعادل كودكان مبتلا به اوتيسم يرداخته بودند ناهمسو مى باشد شايد تفاوت اين يافتهها با بزوهش حاضر تفاوت در نوع مداخله تمرينى باشد (·). در خصوص خرده مقياس سرعت باسخ در كودكان مبتلا به اوتيسم يافتها بيانخر اين است كه بين ميانخين گروه آزمايش و كنترل بعد از تمرينات شناختى حركتى تفاوت معنادارى وجود دارد. تمرينات شناختى حركتى با توجه به اينكه همزمان جنبه هاى حركتى و شناختى را تحت تاثير قرار مى دهد، باعث بهبود سرعت ياسخ مىشود (جس). يافته هاى تحقيق حاضر

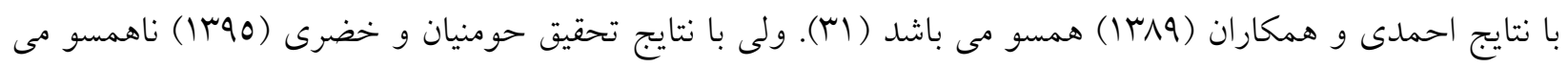
باشد (Yr). از دلايل ناهمسو بودن مى توان به نوع تمرين متفاوت به كار برده در تحقيق حومنيان و خضرى (90با (I) نسبت به تحقيق حاضر اشاره كرد.

اغلب كودكان اوتيسم در حركات دو طرفه و اختلاف بين عملكرداعضاى بالا تنه و باين تنه از خود الكوى ناقصى را نشان مى دهند كه به مشكلات هماهنكى حركتى منجر مى شود. اين مشكلات هماهنكى مربوط به مشكلات بالينى كلى آنها مثل فلج مغزى نيست، يس مى توان با برنامه هاى دقيق اين نارسايى ها را را به حداقل رساند و زمينه بهبود مهارتهاى حركتى را نيز فراهم كرد. تمرين و تجربه بر هماهنكى اين افراد تاثير دارد هر جهه تمرين بيشتر باشد هماهنكى افراد نيز بيشتر مى شود.يافته هاى تحقيق حاضر در بخش هماهنكى با نتايج سراب زاده و همكاران (19 ·. (Y)، احمدى و همكاران 


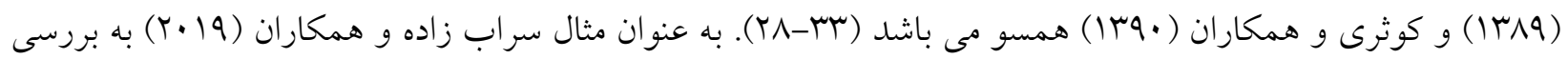
تاثير تمرين تاى جى جهوان بر هماهنكى و تعادل كودكان مبتلا يرداختند و به اين نتيجه رسيدند اين نوع تمرين باعث بهبود هماهنخى و تعادل مى شود.

در خصوص خرده مقياس سرعت دويدن و جابكى در كودكان مبتلا به اوتيسم يافته بيانگر اين است كه بين ميانخين كروه آزمايش و كنترل تفاوت معنادارى وجود دارد با توجه به اينكه كودكان او تيسم با انقباض عضله ضعيف مواجه هستند، اين امر باعث عملكرد ضعيف آنها در مراحل اصلى رشد مانند راه رفتن و دويدن مى شود. تمرينات حركتى شناختى استفاده شده در اين يزوهش موجب بهبود بهبود سيستم حركتى و كاهش اين اختلال شده است. اين يافته ها با نتايج

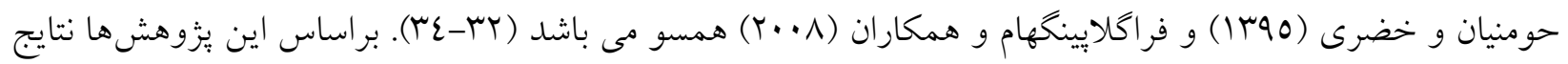
تحقيق حاضر و مى توان كفت كه تمرين و فعاليت بدنى بر توانايى ادراكى و حركتى اين كودكان تاثير زيادى دارد و مى

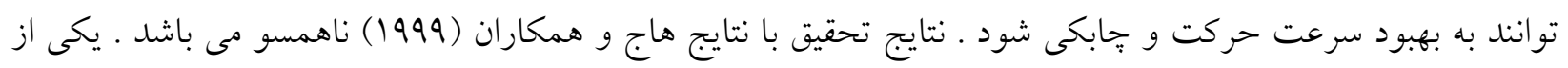
دلايل اصلى ناهمسو بودن تحقيق هاج و همكاران وجود اختلال هاى ديخر همزمان با اختلال اوتيسم مىباشد كه بر نتايج بدست آمده تاثير مى كذارد (T) (r). همانكونه كه در بالا اشاره شد، شش هفته تمرينات شناختى - حركتى طبق مدل جنتايل باعث بهبود مهارتهاى درشت و

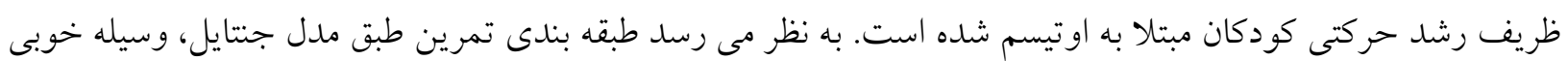
يراى اطلاع يافتن از ويزگگ هاى مهارتى است كه باعث ايجاد مهارت هاى متفاوت از مهارت هاى ديخر مى شود و جهون اجرا در انتهاى اين مهارتها در يك محيطى غير قابل بيش بينى و با تغيير ماهيتى آنها اجرا مى شود، فرض بر اين است كه شرايط تنظيمى متفاوت و در نتيجه ياسخ هاى متفاوتى را تجربه كرده و در نتيجه ياسخ هاى متفاوت، متنوع و مرتبط با نيازهاى متغيرش را خو اهد داد كه وابسته به مراحل مختلف مدل جنتايل خو اهد بود (Y (Y). همجنين استفاده از روش جنتايل با توجه به اينكه طبقه بندى مهارت از ساده به مشكل مى باشد و با توجه به روش تمرينى در تربيت بدنى، كه به سمت

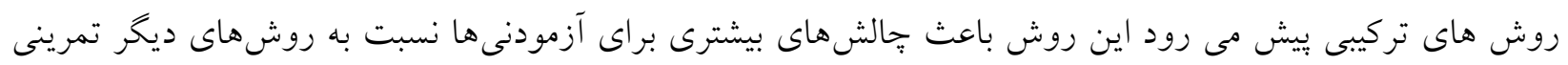
مىشود. همجنين در مورد تمرينات شناختى حركتى استفاده شده در اين تحقيق، با توجه به اينكه اين نوع تمرينات به صورت همزمان جنبه هاى حركتى و شناختى را تحت تاثير قرار مى دهد. كه به طور مؤثرى باعث بهبود هماهنكى حركتى، هرئ آكاهى بدنى، تون عضلانى و در نهايت اعتماد به نفس كودكان مبتلا به اوتيسم مى شود (Tس). بهبود همزمان اين شاخصهـا در نهايت به افزايش كيفيت زندكى همه جانبه اين كودكان مىانجامد، باين حال اين متغير به طور اختصاصى در اين مطالعه مورد بررسى قرار نخرفته است.

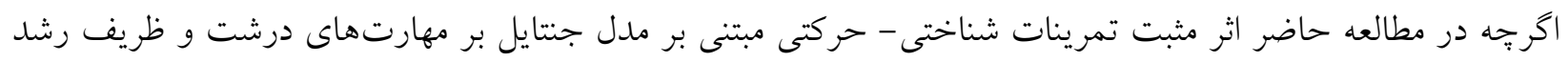
حركتى كود كان مبتلا به اوتيسم مشاهده شد، بايستى عنوان كرد كه متغيرهاى تحقيق حاضر با استفاده از جّى ليست بررسى رفتارى انجام شد و كاركردهاى عينى در موقعيتهاى واقعى به صورت مستقيم بررسى نشده است. به ويزه براى تعميم 


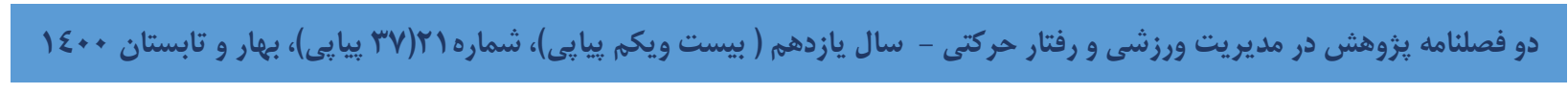

$$
\text { نتئتجن، تأثير انواع مختلف تمرينات شناختى - حركتى بر عملكردهاى اجر ايى كودكان مبتلا به اوتيسم به انجام تحقيقات }
$$

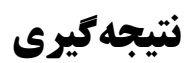

تحقيق حاضر نشان داد تمرينات شناختى حركتى طبق مدل جنتائل باعث بهبود مهارت هاى درشت و ظريف رشد حركتى

كودكان مبتلا به اوتيسم مى شود. با توجه به نتايج مطالعه حاضر به نظر مىرسد استفاده از تمرينات شناختى - حركتى مبتنى

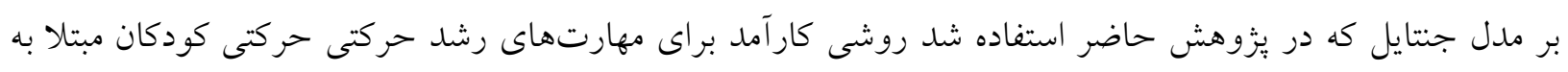
اوتيسم است.

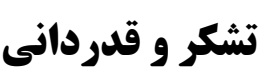

بدين وسيله از همه والدين و كودكان شركت كننده در اين بزوهش و مسئول محترم كلينيك مركز روانشناسى احياء قدردانى و سياسگزارى مىشود.

1. Fombonne E. Modern views of autism. Can J Psychiatry. 2003: 48 (8): 503-5.

2. Baio J, Wiggins L, Christensen DL, Maenner MJ, Daniels J, Warren Z, Kurzius-Spencer M, Zahorodny W, Rosenberg CR, White T, Durkin MS. Prevalence of autism spectrum disorder among children aged 8 years - autism and developmental disabilities monitoring network, 11 sites, United States, 2014. MMWR Surveillance Summaries. 2018 Apr 27;67(6):1.

3. Gao J, He X, Cai Y, Wang L, Fan X. Association between assisted reproductive technology and the risk of autism spectrum disorders in the offspring: a meta-analysis. Scientific reports. 2017 Apr 7;7:46207.

4. Järvinen-Pasley $A$, Heaton $P$. Evidence for reduced domain-specificity in auditory processing in autism. Developmental science. 2007 Nov 1;10(6):786-93.

5. Minjarez MB, Williams SE, Mercier EM, Hardan AY. Pivotal response group treatment program for parents of children with autism. Journal of autism and developmental disorders. 2011 Jan 1;41(1):92-101.

6. Minshew NJ, Sung K, Jones BL, Furman JM. Underdevelopment of the postural control system in autism. Neurology. 2004 Dec 14;63(11):2056-61.

7. Fournier KA, Hass CJ, Naik SK, Lodha N, Cauraugh JH. Motor coordination in autism spectrum disorders: a synthesis and meta-analysis. Journal of autism and developmental disorders. 2010 Oct 1;40(10):1227-40.

8. Bloom, Benjamin, Max, Fred Jay Edward, Hill, Walker, Kraftwall, David. 1374. Translators Ali Akbar Seyf and Khadijeh Ali Abadi. Grow Publishing 1374.

9. May T, Cornish K, Rinehart NJ. Gender profiles of behavioral attention in children with autism spectrum disorder. Journal of attention disorders. 2016 Jul;20(7):627-35.

10. Toscano CV, Carvalho HM, Ferreira JP. Exercise effects for children with autism spectrum disorder: metabolic health, autistic traits, and quality of life. Perceptual and motor skills. 2018 Feb;125(1):126-46.

11. Lee J, Porretta DL. Enhancing the motor skills of children with autism spectrum disorders: A pool-based approach. Journal of Physical Education, Recreation \& Dance. 2013 Jan 
$1 ; 84(1): 41-5$.

12. Lu L, Petersen F, Lacroix L, Rousseau C. Stimulating creative play in children with autism through sandplay. The Arts in Psychotherapy. 2010 Feb 1;37(1):56-64.

13. Matson JL, Hess JA, Boisjoli JA. Comorbid psychopathology in infants and toddlers with autism and pervasive developmental disorders-not otherwise specified (PDD-NOS). Research in Autism Spectrum Disorders. 2010 Apr 1;4(2):300-4.

14. Ahmadi SJ, Safari T, Arab Barani HR, Hemmatian M, Khalili Z, Isfahan Center for Training and Rehabilitation of Autistic Kids. Effectiveness of role playing and Applied Behavior Analysis: Increases social behavior in children with autism. Journal of research inbehavioural sciences. 2014: Volume 12 , Number 3: (s) 351-359. (in persian)

15. Lang R, Koegel LK, Ashbaugh K, Regester A, Ence W, Smith W. Physical exercise and individuals with autism spectrum disorders: A systematic review. Research in Autism Spectrum Disorders. 2010 Oct 1;4(4):565-76.

16. Delacato, cart. The diagnosis and treatment. 1963

17. Fabel K, Kempermann G. Physical activity and the regulation of neurogenesis in the adult and aging brain. Neuromolecular medicine. 2008 Jun 1;10(2):59-66.

18. Langdon KD, Corbett D. Improved working memory following novel combinations of physical and cognitive activity. Neurorehabilitation and neural repair. 2012 Jun;26(5):52332.

19. Voss MW, Vivar C, Kramer AF, van Praag H. Bridging animal and human models of exercise-induced brain plasticity. Trends in cognitive sciences. 2013 Oct 1;17(10):525-44.

20. Schoene D, Lord SR, Delbaere K, Severino C, Davies TA, Smith ST. A randomized controlled pilot study of home-based step training in older people using videogame technology. PloS one. 2013 Mar 5;8(3):e57734.

21. Loomes R, Hull L, Mandy WP. What is the male-to-female ratio in autism spectrum disorder? A systematic review and meta-analysis. Journal of the American Academy of Child \& Adolescent Psychiatry. 2017 Jun 1;56(6):466-74.

22. Azizi H \& Hosseini F. Effect of external and internal focus of attention instructions in field dependence and independence on performance and learning of dart throwin. Motor Behavior. 2015: 7(22), 131-48.

23. Magill RA. Motor learning: Concept and application. USA: McGraw Hill. 2011.

24. Hamid Salehi, Mahshid Zarezadeh and Babak Salek. Validity and Reliability of the Persian Version of Motor Observation Questionnaire for Teachers (PMOQ-T).Iranian Journal of Psychiatryand Clinical Psychology. 2012: Vol. 18, No. 3, 211-219.

25. Silsupadol P, Shumway-Cook A, Lugade V, van Donkelaar P, Chou LS, Mayr U, Woollacott $\mathrm{MH}$. Effects of single-task versus dual-task training on balance performance in older adults: a double-blind, randomized controlled trial. Archives of physical medicine and rehabilitation. 2009 Mar 1;90(3):381-7

26. Sowa M, Meulenbroek R. Effects of physical exercise on autism spectrum disorders: a meta-analysis. Research in Autism Spectrum Disorders. 2012 Jan 1;6(1):46-57.

27. Brausch L. The effect of yoga and breathing exercises on children with autism. 2018: p: 715.

28. Sarabzadeh M, Azari BB, Helalizadeh M. The effect of six weeks of Tai Chi Chuan training on the motor skills of children with Autism Spectrum Disorder. Journal of bodywork and movement therapies. 2019 Apr 1;23(2):284-90.

29. Cheldavi H, Shakerian S, Boshehri SN, Zarghami M. The effects of balance training intervention on postural control of children with autism spectrum disorder: Role of sensory information. Research in Autism Spectrum Disorders. 2014 Jan 1;8(1):8-14.

30. Memari AH, Ghanouni P, Shayestehfar M, Ziaee V, Moshayedi P. Effects of visual search

https://jrsm.khu.ac.ir/ 
vs. auditory tasks on postural control in children with autism spectrum disorder. Gait \& posture. 2014 Jan 1;39(1):229-34.

31. Ahmadi A, Shahi Y. Effect Effect of perceptual-motor practices on motor and mathematical skills in autism, a single-subject design. Fundamentals of Mental Health 2010; 12(2): 53441.

32. Homanian D, Khezri A. The Effect of Paaryaad Training on the Development of Motor Skills of 6-8-Year-Old Children Suffering from High Function Autistic Spectrum. Journal of development and Motor learning.1395: Volume 8, Number 3. Page 531-545.

33. Kosari S, Keyhani f, Hemayat talab R, arabameri E. Effect of a Selected Physical Activity Program on the Development of Motor Skills in Attention Deficit /Hyperactivity Disorder (ADHD) and Autism (HFA) Children. Journal of Motor Learning and Movement.1390: Volume 4, Issue 2 :Pages 45-60.

34. Fragala-Pinkham M, Haley SM, O'Neil ME. Group aquatic aerobic exercise for children with disabilities. Developmental Medicine \& Child Neurology. 2008 Nov;50(11):822-7.

35. Hodge, SR. Murata, NM. Porretta, DL. Enhancing motor performance through various preparatory activities involving children with learning disabilities. Clin Kinesiol: 1999 :53(4): $\mathrm{P}: 76-82$.

36. Theill N, Schumacher V, Adelsberger R, Martin M, Jäncke L. Effects of simultaneously performed cognitive and physical training in older adults. BMC neuroscience. 2013;14(1):103. 